\title{
Secondary acute myeloblastic leukemia after adjuvant chemotherapy and radiotherapy in breast cancer: A case report
}

\author{
Mardiah Suci Hardianti*, Johan Kurnianda, Kartika Widayati Taroeno-Hariadi \\ Division of Hematology-Medical Oncology, Department of Internal Medicine, Dr. Sardjito \\ General Hospital/ Faculty of Medicine Universitas Gadjah Mada, Yogyakarta, Indonesia
}

\section{ABSTRACT}

A rising number of long-term survivors and potential long-term outcome related to the treatment is one of the most important issue due to the advances of management in cancer. The development of secondary malignancy has been reported in a number of cohorts. We present a case of breast cancer patient developing acute myeloid leukemia (AML)- M5 within a relatively short interval of two and a half years from her primary treatment with adjuvant chemotherapy with 4 cycles of doxorubicin and cyclophosphamide, followed by 4 cycles of three weekly paclitaxel (AC-T) and radiotherapy. What could be attributed to the occurrence of secondary leukemia in this patient will be discussed.

\section{ABSTRAK}

Kondisi klinis yang dialami dalam jangka waktu panjang oleh seseorang penderita kanker yang telah berhasil melewati jangka waktu lama setelah terdiagnosis (long term-survivor) merupakan hal penting yang harus diperhatikan karena jumlah yang semakin meningkat. Hal ini tentu tidak terlepas dari berbagai kemajuan dalam penatalaksanaan kanker. Perkembangan keganasan sekunder merupakan salah satu hal yang sering dilaporkan. Kami melaporkan kasus seorang penderita kanker payudara yang berkembang menjadi leukemia mieloid akut tipe M5 dalam jangka waktu yang relatif pendek yakni 2,5 tahun setelah pasien menyelesaikan kemoterapi ajuvan sebanyak 4 siklus dengan doxorubicin dan cyclophosphamide, diikuti 4 siklus paclitaxel tiga mingguan (AC-T) dan radioterapi. Hal-hal apa saja yang mungkin berperan dalam kejadian keganasan berupa leukemia sekunder pada pasien ini akan dibahas dalam laporan kasus ini.

Keywords: breast cancer- secondary leukemia- adjuvant chemotherapy-radiotherapy-breast cancer

\section{INTRODUCTION}

Despite the high incidence of breast cancer (BC), the mortality rate is declining. This might be related to advances in the better diagnostics and treatment modalities. ${ }^{1,2}$ Consequently, there is a rising number of long-term survivors and increasing attention must be focused on the potential long-term outcome related to the treatment that could affect the overall quality of patient survival. Among the potential long-term effect of cytotoxic agents used to treat breast cancer, the development of secondary leukemia (SL) has been evaluated in a number of different cohorts of patients. ${ }^{3}$ Possible causal relationship between the prior chemotherapy, radiotherapy, combined chemotherapy and radiotherapy, and the occurrence of SL in BC had also been proposed. ${ }^{4}$

\footnotetext{
$\overline{\text { * corresponding author: diahbudiyanto@yahoo.com }}$
} 


\section{CASE PRESENTATION}

A female, 50 years old, was diagnosed with cancer of left breast in June $17^{\text {th }}$, 2008. She started to notice a small lump in her left breast in June 2008 before then she proceeded to have a mammography which confirmed a suspicious abnormality Breast Imaging Reporting and Data System (BI-RADS 4). A fine needle aspiration was done with result of positive for malignant cells. A modified radical mastectomy was performed. Pathology of the tumor was infiltrative ductal carcinoma grade II metastasis to one of three regional nodes. Estrogen and progesterone receptors were positive, c-erbB2 (Her2Neu) was found to be negative by immunohistochemistry. She was treated with adjuvant chemotherapy of 4 cycles
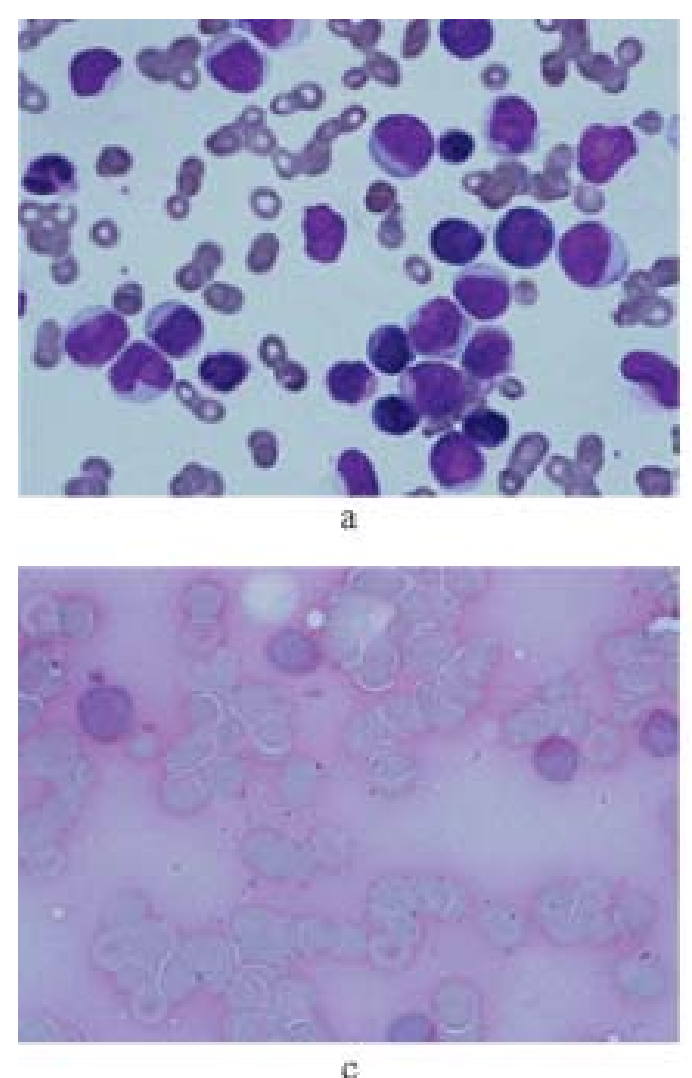

of doxorubicin 60mg/m2 and cyclophospamide $600 \mathrm{mg} / \mathrm{m} 2$, followed by three weekly paclitaxel $175 \mathrm{mg} / \mathrm{m} 2$. The doses based on her body surface area were doxorubicin 100mg and cyclophosphamide $1.000 \mathrm{mg}$ given in every 3 weeks for 4 cycles. The following paclitaxel dose was 300mg for each cycle given in every 3 weeks for 4 cycles. The cumulative doses of drugs administered were doxorubicin $400 \mathrm{mg}$, cyclophosphamide $4.000 \mathrm{mg}$ and paclitaxel $1.200 \mathrm{mg}$. She did not need any support for granulocyte stimulating factors during her chemotherapy courses. After completion of chemotherapy series over 5 weeks, she received radiotherapy for a total dose of 52 Gray in 26 fractions by Cobalt- 60 completed on March $4^{\text {th }}$, 2009. Tamoxifen $20 \mathrm{mg}$ daily was also started to be given for 5 years.

She had been in good condition and had no
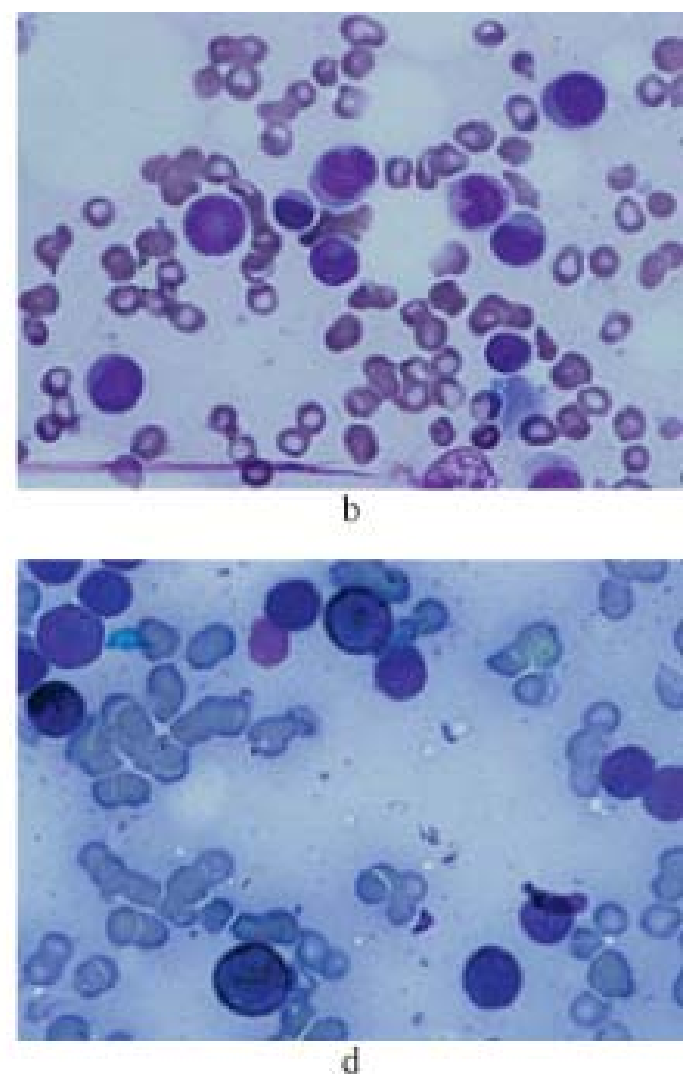

FIGURE 1. a) Peripheral blood smear, b). Bone marrow smear stained by May Gruenwald Giemsa, c). Bone marrow smear: fine granules of the monoblasts were stained by PAS, d). Bone marrow smear: granules of the myeloblasts and monoblasts were stained strongly and weakly respectively by SBB 
abnormal laboratory results until August $2^{\text {nd }}, 2011$ when she visited in the outpatient clinic with complaints of fever, sore throat and mouth, bone pain and non-productive cough in the last 2 weeks. A complete blood count revealed her leukocyte count of $160 \times 10^{9} / \mathrm{L}$, hemoglobin level of $9.9 \mathrm{gr} / \mathrm{dL}$, and platelet count of $74 \times 10^{9} / \mathrm{L}$. A peripheral blood smear showed leukocytosis with $72 \%$ blast resembling myeloid cells accompanied with normocytic normochromic anemia and thrombocytopenia. A bone marrow punction was done on the sternum showing result of an increase inmyeloid seri with $61 \%$ myeloblast and $15 \%$ monoblast. Fine granules of the monoblasts were stained by periodic acid Schiff (PAS). Granules of the myeloblasts and monoblasts were stained strongly and weakly respectively by sudan black blue (SBB), confirming the diagnosis of AML-M4 (FIGURE 1). A cytogenetic analysis showed a normal karyotype (FIGURE 2). She expired two days after the diagnosis of acute leukemia, before induction treatment was commenced. She died in a sudden death during her visit to the out patient clinic, on August $11^{\text {th }}$, 2011, possibly due to leukostasis syndrome. Her last blood count showed leukocyte count of $213.3 \times 10^{9} / \mathrm{L}$, hemoglobin level of $9.1 \mathrm{gr} / \mathrm{dL}$, and platelet count of $51 \times 10^{9} / \mathrm{L}$.
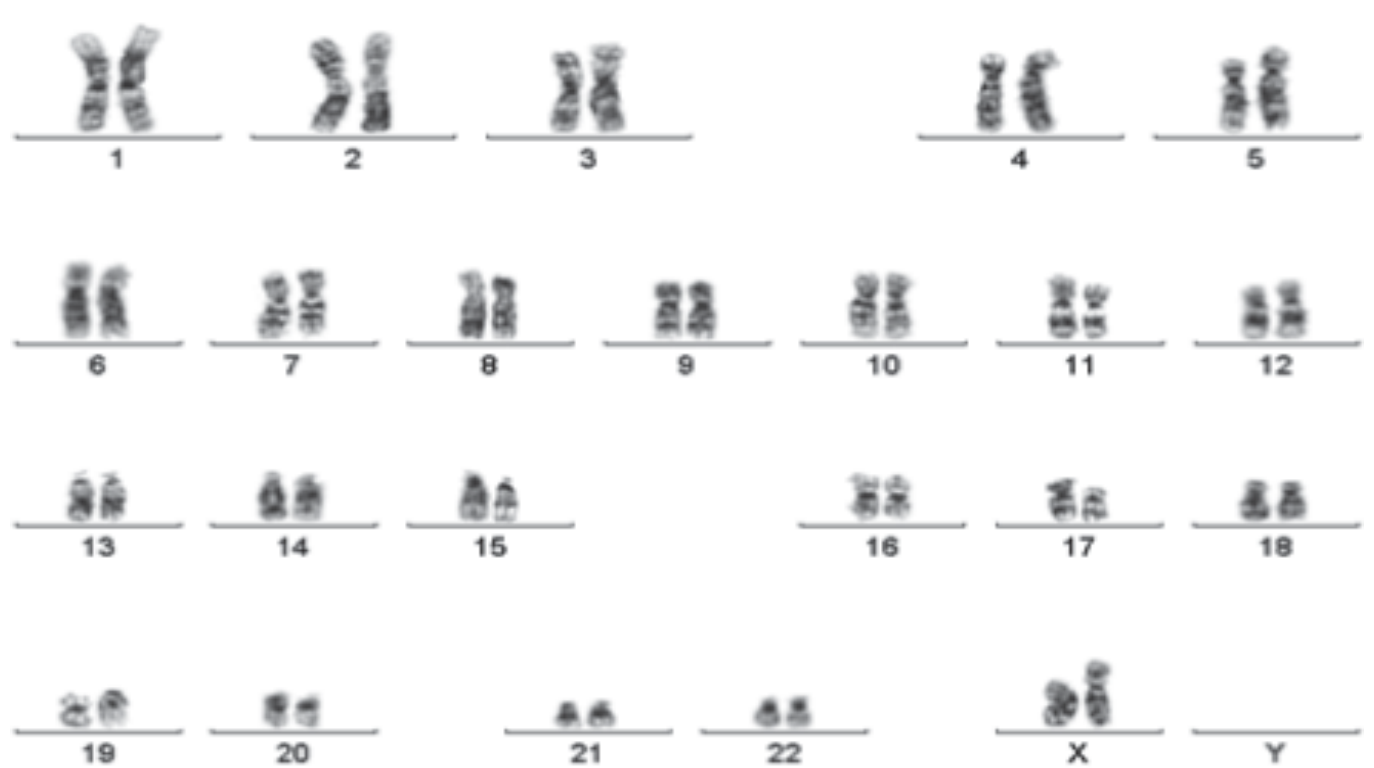

FIGURE 2. Cytogenetic analysis showed a normal karyotype

\section{DISCUSSION}

\section{Prolonged survival in breast cancer patients}

Breast cancer is the most frequently diagnosed cancer among women in most developed countries and accounted for about one-third $(\mathrm{n}=207.090)$ of all new cancer cases in U.S. women in 2010. ${ }^{5}$ Survival after a diagnosis of BC has steadily improved, due largely to earlier detection and the application of effective treatment regimens, thus, given a current 5- year relative survival rate of almost $90 \% .^{5}$ The improvement of survival rate in $\mathrm{BC}$ is due to the contribution of significant progress in the management of $\mathrm{BC}$ including better chemotherapy and radiation treatment options and guidelines based on diagnostic tumor characteristics. ${ }^{3}$ As of January 2008, it is estimated 
that there are 11.9 million cancer survivors which represented approximately $4 \%$ of the population, among which women with $\mathrm{BC}$ are the most common survivors. ${ }^{6}$ This burgeoning number underscores the importance of quantifying late adverse effects of cancer therapy, which can influence cancer treatment practices and patient survival.

\section{Incidence of secondary AML in BC}

Secondary non-breast cancer (SNBC) including secondary hematologic malignancy (SHM) particularly acute myeloid leukemia (AML) and myelodysplastic syndrome (MDS) are among several potential long-term adverse events associated with adjuvant chemotherapy in breast cancer which have been described. Moreover, cardiac toxicity, cognitive function, neurotoxicity and problem related with reproductive problems and sexuality were also described. ${ }^{7}$ It is estimated that 1 in every 20 patients will develop an SNBC in 10 years after diagnosis of breast cancer, which corresponds to a $22 \%$ increase in the relative risk. ${ }^{8}$

Therapy related acute myeloid leukemia or myelodysplastic syndromes (t-AML/MDS) are collectively known as therapy-related myeloid neoplasms (t-MN) included among "Acute myeloid leukemias and precursor neoplasms" in the 2008 WHO classification. The term "therapy-related" leukemia is descriptive and based on patient's history of exposure to cytotoxic agents. The latency between primary diagnosis and therapy-related disease ranges from few months to several years, with a median of about two years, depending on several factors. Beside therapy-related forms, there are AML/MDS defined as "second malignancy" arising as second cancer after a previous diagnosis of a neoplasm treated with surgery alone or without any exposure to any systemic therapy. ${ }^{9}$

Yu et al. ${ }^{10}$ reported an increase in incidence of secondary leukemia in BC patients by about $300 \%$ from 8 per 100.000 person-years in the 1970 s to 32 per 100.000 person-years in the 1990s among young patients aged 20-49. A registry cohort analysis from 1990-2005 including $5.790 \mathrm{BC}$ patients reported 17 incident cases of MDS with 10 MDS and 7 AML with median time from BC to MDS/AML diagnosis was 4.35 years and median time from radiation or chemotherapy was 3.06 years. ${ }^{3}$

In this case, AML-M5 was diagnosed at 3 years after the initial diagnosis of breast cancer, and at 2.5 years post treatment by adjuvant chemotherapy and radiation.

\section{Adjuvant chemotherapy and Secondary leukemia}

During the past few decades, we have witnessed a paradigm shift of BC treatment, moving from classic CMF (cyclophosphamide, methotrexate, and 5-fluorouracil) to anthracycline-based regimens, to the subsequent incorporation of taxanes, administration of dose-dense regimens, and, most recently, the use of biological agents. ${ }^{11}$ Secondary leukemia risk has been evaluated in many studies of commonly used alkylating agents and anthracyclines.

The antineoplastic activity of alkylating agents is related to their ability to damage Deoxyribonucleade Acid (DNA) by methylation or DNA inter-strand crosslinks formation, interfering with normal DNA replication. Of the commonly used alkylating agents, melphalan is highly leukemogenic, while cyclophosphamide is graded at a lower scale, possibly on account of it's relatively stem cell sparing effect. Alkylating agent-related AML typically develops after an average latency of 5-7 years, and overt leukemia is often (up to $70 \%$ of cases) proceeded by a dysplastic phase. ${ }^{7}$ Fisher et al reported that the 10-year cumulative risk of AML was increased in BC patients treated with surgery followed by melphalan based 
chemotherapy compared to those treated with surgery alone (1.29\% versus $0.27 \%$, respectively). ${ }^{12}$ In the following years the leukemogenic potential of cyclophosphamide has emerged. A combined analysis of six adjuvant studies conducted by the National Surgical Adjuvant Breast and Bowel Project group involving 8,536 patients using cyclophosphamide and doxorubicin (AC) reported a 5-year incidence of AML ranging from $0.3 \%$ to $1.2 \%$. Higher risk was associated with greater dose intensity of AC requiring GCSF support. Breast radiotherapy also appeared to be associated with an increased risk of AML/ MDS. ${ }^{13}$

The latency period between exposure to anthracyclines and the onset of leukemia is usually about 2 years, and generally there is no previous myelodysplastic phase. The Epirubicin Monitoring Plan is the most comprehensive analysis of secondary leukemia after treatment with adjuvant epirubicin completed to date, with
9.796 patients observed for a total of 53.080 patients. The analysis confirms a small but significant risk of AML/MDS in patients treated with adjuvant epirubicin and cyclophosphamide for early breast cancer. In all of the 7.110 patients treated with epirubicin-containing regimens, the 8-year cumulative probability of AML/MDS was $0.55 \%$. The risk of developing AML/MDS increased in relation to total dose of epirubicin and total dose of cyclophosphamide, with a steep increase at cumulative doses above those used in recommended regimens for adjuvant therapy (epirubicin up to $720 \mathrm{mg} / \mathrm{m}^{2}$ and cyclophosphamide up to $6.300 \mathrm{mg} / \mathrm{m}^{2}$ ). The highest risk (4.97\% cumulative probability at 8 years) was seen in patients who had been administered greater than standard doses of both epirubicin and cyclophosphamide. ${ }^{14}$

Antineoplastic activity of taxanes appears to be related to their ability to promote microtubular

TABLE 1. The incidence of AML/MDS in BC following adjuvant chemotherapy

\begin{tabular}{|c|c|c|c|}
\hline & Smith et al., 2003 & Praga et al., 2005 & Burnell et al., 2010 \\
\hline $\begin{array}{l}\text { Cumulative } \\
\text { dose } \\
(\mathbf{m g} / \mathbf{m} 2)\end{array}$ & $\begin{array}{l}\text { AC: } 240 / 2400 \\
\text { High dose C } \geq 4800\end{array}$ & $\begin{array}{l}\text { Group A; } \\
E \leq 720 \\
C \leq 6300 \\
\text { Group B } \\
E \geq 720 \\
C \geq 6300\end{array}$ & $\begin{array}{l}\text { CEF: } \\
6300 / 720 / 300 \\
\text { EC - T Q2W: } \\
480 / 3320 / 700 \\
\text { AC - T: } \\
240 / 2400 / 700\end{array}$ \\
\hline $\begin{array}{l}\text { Median } \\
\text { follow up }\end{array}$ & 5 years & 8 years & 30.4 months \\
\hline $\begin{array}{l}\text { Incidence } \\
(\%)\end{array}$ & $\begin{array}{l}\text { AC: } 0.21 \\
\text { High dose C: } 1.01\end{array}$ & $\begin{array}{l}\text { Group A: } 0.37 \\
\text { Group B: } 4.97\end{array}$ & $\begin{array}{l}\text { CEF: } 0.57 \\
\text { EC - T: } 0.57 \\
\text { AC - T: } 0\end{array}$ \\
\hline
\end{tabular}

assembly and to inhibit microtubular disassembly. A 7-year update of a study (1.016 subjects with operable stage I to III invasive BC) comparing AC with TC showed no secondary leukemia in the TC arm, when compared with 2 of 510 cases
(0.4\%) in the AC arm. Leukemia and myelodysplasia are major anthracycline related toxicities in women with breast cancer treated with anthracyclines and another reason for considering nonanthracycline regimens. Because there were 
only two cases in this study, no attempt was made to look for the use of adjuvant radiation therapy as a contributing factor. ${ }^{15} \mathrm{~A}$ three-arm study comparing the Canadian CEF with 2weekly dose-dense EC followed by $\mathrm{T}$ and with 3-weekly AC followed by T showed that $0.5 \%$ of patients developed AML in the first two arms. This is mainly attributed to the high cumulative dose of epirubicin and perhaps the use of GCSF to support chemotherapy. However, no secondary leukemia was diagnosed in patients randomly assigned to the AC-T arm. ${ }^{16} \mathrm{TABLE}$ 1 shows the incidence of AML/MDS in BC following adjuvant chemotherapy with various regiments.

In this case, the patient was treated with adjuvant chemotherapy of 4 cycles of doxorubicin and cyclophospamide, followed by 3 weekly paclitaxel. The doses based on her body surface area were- doxorubicin 100mg and cyclophosphamide 1,000mg given in every 3 weeks for 4 cycles. The following paclitaxel dose was 300mg for each cycle given in every 3 weeks for 4 cycles. The cumulative doses of drugs administered were doxorubicin 400mg, cyclophosphamide $4.000 \mathrm{mg}$ and paclitaxel $1.200 \mathrm{mg}$. This dose is much lower than the maximum cumulative dose for cyclophosphamide shown to be related with the increased incidence of secondary AML/MDS. ${ }^{13}$ Regarding taxane, two studies failed to show the attribution of paclitaxel in the incidence of secondary AML/MDS after adjuvant treatment by taxane combination. ${ }^{15,16}$

\section{Role of Granulocyte Colony-Stimulating Factors (G-CSF)}

Administration of granulocyte stimulating factors in women receiving adjuvant chemotherapy for BC is aimed to reduce the myelosuppressive effects of dose intense chemotherapy. An analysis of the Surveillance, Epidemiology, and End Realis (SEER) medicare population-based database including 5.510 women with BC treated with adjuvant chemotherapy, found that the addition of G-CSF is associated with a doubling of the risk of subsequent AML or MDS when compared with chemotherapy alone, even if the absolute risk is low. ${ }^{17}$ In the analysis of six trials described by Smith et al. ${ }^{13}$ in 2003, the incidence of therapy-related leukemia was sharply elevated in patients treated with intensified regimens that required G-CSF support (relative risk 6.16; $\mathrm{p}=0.0001$ ). Finally, a systematic review of 25 randomized clinical trials was recently conducted to evaluate the risk of AML or MDS in patients receiving chemotherapy for solid malignancies and lymphomas with or without the addition of G-CSF. At a median follow up of 54 months, the estimated relative risk for AML/MDS with G-CSF-supported chemotherapy was 1.92 , with an estimate absolute increase in risk of $0.4 \% .{ }^{18}$ However, as relative dose intensity (RDI) was also reported to be higher in patients with growth factor support, the authors concluded that it was not possible to distinguish between the effects of G-CSF and the effects of a higher delivered dose of leukaemogenic chemotherapy agents.

In this case, the patient never had any supports of G-CSF during the courses of chemotherapy with sequential AC-T.

\section{Radiotherapy and secondary leukemia}

Radiotherapy may also play a significant role in SL occurrence in BC patients. Several studies report higher risk of leukemia in BC patients given combined modality treatment compared to chemotherapy or radiotherapy alone. ${ }^{19,20}$ The radiation-related risk of secondary leukemia was about 2.4 in patients who were not treated with chemotherapy, compared to 17.4 in patients who were treated with both radiation and chemotherapy. ${ }^{19} \mathrm{In}$ another study, the risk of developing AML was 
increased by fourfold when radiotherapy treatment was received $(\mathrm{HR}=4.0 ; 95 \%$ $\mathrm{CI}=1.4-11.8$ ) and increased by sevenfold when radiotherapy was combined with chemotherapy treatment $(\mathrm{HR}=7.2 ; 95 \% \mathrm{CI}=1.4-36.3) .{ }^{21} \mathrm{~A}$ cohort study analyzing clinical records of BC patients with the aim of evaluating the long-term effect of radiotherapy on the risk of second cancers reported a total of 387 malignancies (7.3\%) in 5248 women, with eight patients developing leukemia $(0.15 \%)$, seven in the group treated with radiotherapy, versus one case only in the group not receiving radiotherapy. The relative risk adjusted for chemotherapy and hormone treatment was 6.67 (95\% CI= 0.7658.00) and the median time from exposure was 4.5 years, with the suggestion of a raised incidence of leukemia within the first two or more years after radiotherapy. ${ }^{22}$

In our patient, she received radiotherapy for a total dose of 52 Gray in 26 fractions by cobalt-60 after the completion of AC-T courses. Secondary AML in this patient was diagnosed at 2.5years later after the completion of radiotherapy. Since the risk of chemotherapy alone was not markedly increased in this case as the cumulative dose of the cyclophosphamide being less than the maximum cumulative dose shown to be related with the increased incidence of secondary AML/MDS. ${ }^{13}$ The left possible reason though not clearly ascertainable could be the synergistic effect of radiation and chemotherapy.

\section{Genetic factors}

Acute myeloid leukemia develops as a result of acquired, non-random somatic mutations in hematopoietic progenitor cells. These mutations are found in the majority of cases, with higher frequencies seen in leukemia attributed to chemotherapy and advancing age. Reports of a short time course to MDS and
AML, and a recent study of GCSF use in BC support the possibility that treatment accelerates the development of molecular events in cells predestined to progress to AML. In support of this theory, an association of treatment-related leukemia with a polymorphism in the gene for CYP3A4, an enzyme that metabolizes many chemotherapeutic agents, has been described. ${ }^{23}$ On the other hand, it has been shown that Secondary Hematological Malignancies (SHM) can develop even in BC patients who were treated with surgery alone. For these patients it may be hypothesized that secondary AML develops after a previous BC because of a genetic predisposition to neoplastic processes. ${ }^{24}$ Some of this risk is related to genetic predisposition (BRCA2 and p53 carriers). ${ }^{25} \mathrm{~A}$ study to further explore a genetic link for SHM following BC, the impact of a positive family history for breast/ovarian cancer on the risk of SHM following BC has been done and concluded that among BC patients, family history was independently associated with the development of leukemia. ${ }^{26}$

\section{AML subtype and chromosomal aberration in secondary AML in BC}

Alkylating agent-related AML has been frequently described as being either M1 or M2 according to french American Britih (FAB) classification. Karyotypic analysis shows alterations of chromosomes 5 and 7 in 60\% to $90 \%$ of cases. The most common cytogenetic findings are losses of chromosomes 5 or 7 and deletions at 7q. A cytogenetic study including 14 patients with secondary AML with prior treatment for BC with alkylating agents reported that chromosomes $7,5,17$, and 11 are recurrently involved in numerical or structural anomalies. They also reported 2 cases with normal karyotype. $^{27}$

AML/MDS associated with topoisomerase 
II inhibitor (doxorubicin, epipodophyllotoxin) treatment present as either FAB M4 or M5 and are frequently associated with translocation of the long arm of chromosome 11 (11q23) involving mixed-lineage leukemia (MLL) gene. These translocations of the MLL gene result in its fusion with a variety of partner genes resulting in abnormal gene expression in hematopoietic stem cells and subsequent development of leukemia. Other abnormalities including MLL partial tandem duplication, MLL amplification, core binding factor (CBF) translocations [namely t $(8 ; 21)$ and inv(16)], and PML-Retinoic Acid Receptor Alpha (PMLRAR- $\alpha$ ) translocations have also been described in therapy-related leukemia. Refractory Anemia with Excess Blasts (RAEB) and Refractory Anemia with Excess Blasts in Transformation (RAEB-t) have been found to be the most common types of chemotherapyinduced MDS..$^{13}$ The addition of radiotherapy appears to modulate susceptibility to cytogenetic aberrations and is more often associated with deletions or unbalanced mutations. ${ }^{25}$ In this case, the analysis of chromosome did not reveal any chromosomal aberrations.

\section{CONCLUSION}

Based on the subtype of AML-M5 and its early occurrence at two and half years from her primary treatment, we may suggest that it may be related to the treatment given although the chromosomal data did not show any specific alteration. However, we still could not exclude the possibility that the secondary leukemia arose in this patient may be part of a cancer-risk syndrome involving breast cancer, and possibly a general cancer susceptibility. To the best of our knowledge, this is the first case to be reported in the Indonesian subjects as per the Medline search.

\section{ACKNOWLEDGEMENT}

Author would like to extend her gratitude to the family of the patient for their cooperation during the treatment and case writing process.

\section{REFERENCES}

1. De Santis C, Siegel R, Bandi P, Jemal A. Breast cancer statistics. CA Cancer J Clin 2011; 61(6):409-18.

2. Jemal A, Bray F, Center MM, Ferlay J, Ward E and Forman D. Global cancer statistics 2011. CA Cancer J Clin 2011; 61(2): 69-90

3. Kaplan HG, Malmgren JA, Atwood MK. Increased incidence of myelodysplastic syndromeand acute myeloid leukemia following breastcancer treatment with radiation alone orcombined with chemotherapy: a registry cohortanalysis 19902005. BMC Cancer 2011, 11:260.

4. Valentini CG, Fianchi L, Voso MT, Caira M, Leone G, Pagano L. Incidence of acute myeloid leukemia after breast cancer. Mediterr J Hematol Infect Dis 2011;3(1):e2011069.

5. Jemal A, Siegel R, Xu J, Ward E. Cancer statistics 2010. Cancer J Clin 2010; 60(5): 277-300.

6. DeSantis C, Howlader N, Cronin KA, Jemal A. Breast cancer incidence rates in U.S. women are no longer declining. Cancer Epidemiol Biomarkers Prev 2011; 20(5):733-9.

7. Azim HA, de Azambuja E, Colozza M, Bines J, Piccart MJ. Long-term toxic effects of adjuvant chemotherapy in breast cancer. Ann Oncol 2011; 22:1939-47.

8. Schaapveld M, Visser O, Louwman MJ, de Vries EG, Willemse PH, Otter R, et al. Risk of new primary non breast cancers after breast cancer treatment: a Dutch population-based study. J Clin Oncol 2008; 26(8):1239-46.

9. Vardiman JW, Thiele J, Arber DA, Brunning RD, Borowitz MJ, Porwit A, et al. The 2008 revision of the World Health Organization (WHO) classification of myeloid neoplasms and acute leukemia: rationale and important changes. Blood 2009; 114(5): 937-51.

10. Yu GP, Schantz SP, Neugut A, Zhang Z. Incidences andtrends of second cancers in female breast cancer patients: a fixed inception cohort-based analysis (United States). Cancer Causes Control 2006;17(4):411-20.

11. Colozza M, de Azambuja E, Cardoso F, Bernard C,Piccart MJ. Breast cancer: achievements in 
adjuvant systemic therapies in the pre-genomic era. The Oncologist 2006;11:111-25.

12. Fisher B, Rockette H, Fisher ER, Wickerham DL, Redmond C, Brown A. Leukemia after breast cancer patients following adjuvant chemotherapy or postoperative radiation: The NSABP experience. J Clin Oncol 1985; 3:1640-58.

13. Smith RE, Bryant J, DeCillis A, and Anderson S. Acute myeloid leukemia and myelodysplastic syndrome after doxorubicin-cyclophosphamide adjuvant therapy for operable breast cancer: The National Surgical Adjuvant Breast and Bowel Project Experience. J Clin Oncol 2003; 21(7):1195-204.

14. Praga C, Bergh J, Bliss J, Bonneterre J, Cesana B, Coombes RC, et al. Risk of acute myeloid leukemia and myelodysplastic syndrome in trials of adjuvant epirubic in for early breast cancer: Correlation with doses of epirubicin and cyclophosphamide. J Clin Oncol 2005; 23(18):4179-91.

15. Jones S, Holmes FA, O’Shaughnessy J, Blum JL, Vukelja SJ,McIntyre KJ, et al. Docetaxel with cyclophosphamide is associated with an overall survival benefit compared with doxorubicin and cyclophosphamide: 7-year follow-up of US oncology research trial 9735. J Clin Oncol 2009; 27(8):1177-83.

16. Burnell M, Levine MN, Chapman JW, Bramwell V, Gelmon K,Walley B, et al. Cyclophosphamide, epirubicin, and fluorouracil versus dose-dense epirubicin and cyclophosphamide followed by paclitaxel versus doxorubicin and cyclophosphamide followed by paclitaxel in node-positive or highrisk node-negative breast cancer. J Clin Oncol 2010;28(1):77-82.

17. Hershman D, Neugut AI, Jacobson JS, Wang J, Tsai W, McBride R, et al. Acute myeloid leukemia or myelodysplastic syndrome following use of granulocyte colony-stimulating factors during breast cancer adjuvant chemotherapy. J Natl Cancer Inst 2007; 99: 196-205.

18. Lyman GH, Dale D, Wolff D, Culakova E, Poniewierski MS, Kuderer NM, et al. Acute myeloid leukemia or myelodysplastic syndrome in randomized controlled clinical trials of cancer chemotherapy with granulocyte colony-stimulating factor: A systematic review. J Clin Oncol 2010; 28(17):2914-24.

19. Curtis RE, Boice JD, Stovall M, Bernstein L, Greenberg RS, Flannery JT, et al. Risk of leukemia after chemotherapy and radiation treatment for breast cancer. N Engl J Med 1992;326:1745-51.

20. Chaplain G, Milan C, Sgro C, Carli P, and Bonithon-Kopp C. Increased risk of acute leukemia after adjuvant chemotherapy for breast cancer: A population-based study. J Clin Oncol 2000;18(15): 2836-42.

21. Renella R, Verkooijen HM, Fioretta G, Vlastos G, Kurtz J, Sappino AP, et al. Increased risk of acute myeloid leukaemia after treatment for breast cancer. Breast 2006;15(5):614-9.

22. Zhang W, Becciolini A, Biggeri A, Pacini P, Muirhead CR. Second malignancies in breast cancer patients following radiotherapy: A study in Florence, Italy. Breast Cancer Research 2011, 13(2):R38.

23. Felix CA, Walker AH, Lange BJ, Williams TM, Winicki NJ, Cheung NV, et al. Association of CYP3A4 genotype with treatment-related leukemia. Proc Natl Acad 1998; 95:13176-81.

24. Pagano L, Pulsoni A, Mele L, Tosti ME, Cerri R, Visani G, et al. Acute myeloid leukemia in patients previously diagnosed with breast cancer: experience of the GIMEMA group. Ann Oncol 2001;12(2):2037.

25. Bayraktar S and Escalon MP. Secondary hematological malignancies following breast cancer treatment. Oncol Rev 2010;4:51-9.

26. Verkooijen HM, Fioretta G, Rapiti E. Family history of breast or ovarian cancer modifies the risk of secondary leukemia after breast cancer: results from a population-based study. Int J Cancer 2008;122(5): 1114-7.

27. Mamuris Z, Dumont J, Dutrillaux B, Aurias A. Specific chromosomal mutagenesis observed in stimulated lymphocytes from patients with SANLL. Int J Cancer 1990;46(4):563-8. 